\title{
Conversion of Amylase-secreting Rat Pancreatic AR42J Cells to Neuronlike Cells by Activin A
}

\author{
Hirohide Ohnishi, " Nozomi Ohgushi, " Shigeyasu Tanaka, * Hideo Mogami, ${ }^{*}$ Romi Nobusawa," Hirosato Mashima, * \\ Megumi Furukawa, * Tetsuya Mine, ${ }^{\ddagger}$ Osamu Shimada, ${ }^{5}$ Harunori Ishikawa, ${ }^{\S}$ and Itaru Kojima* \\ ${ }^{*}$ Institute for Molecular and Cellular Regulation, Gunma University, Maebashi 371; ${ }^{\ddagger}$ Fourth Department of Internal Medicine, \\ University of Tokyo School of Medicine, Tokyo 112; and ${ }^{\S}$ Department of Anatomy, Gunma University School of Medicine, Maebashi \\ 371, Japan
}

\begin{abstract}
When AR42J cells, an amylase-secreting pancreatic exocrine cell line, were treated with activin $A$, cells extended neuritelike processes, and, concomitantly, amylase-containing vesicles disappeared. Immunofluorescence and immunoelectron microscopy revealed that these processes had neurite-specific cytoskeletal architectures: neurofilaments and microtubule bundles with cross-bridges of microtubuleassociated protein 2. In addition to such morphological changes, activin-treated cells exhibited a marked increase in cytoplasmic free calcium concentration in response to depolarizing concentration of potassium. Moreover, activintreated AR42J cells expressed mRNA for $\alpha_{1}$ subunit of the neuroendocrine/ $\beta$ cell-type voltage-dependent calcium channel. In naive AR42J cells, a sulfonylurea compound, tolbutamide, did not affect free calcium concentration, while it induced a marked elevation of free calcium in activintreated cells. Single channel recording of the membrane patch revealed the existence of ATP-sensitive potassium channel in activin-treated cells. These results indicate that activin A converts amylase-secreting AR42J cells to neuronlike cells. Given that pancreatic endocrine cells possess neuronlike properties and express ATP-sensitive potassium channel as well as neuroendocrine/ $\beta$ cell-type voltage-dependent calcium channel, activin treatment of $A R 42 J$ cells may provide an in vitro model system to study the conversion of pancreatic exocrine cells to endocrine cells in islets. (J. Clin. Invest. 1995. 95:2304-2314.) Key words: differentiation • pancreatic acinar cell $\bullet$ pancreatic islet $\bullet$ cytoskeleton - calcium channel
\end{abstract}

\section{Introduction}

Activin A is a homodimeric protein with a molecular mass of $25 \mathrm{kD}$ originally isolated from ovarian fluid as a stimulant for follicle-stimulating hormone secretion (1). Based on its molecular structure, activin A is considered to be a member of the TGF- $\beta$ supergene family (2). Subsequent studies have revealed

Address correspondence to Itaru Kojima, Institute for Molecular and Cellular Regulation, Gunma University, Maebashi 371, Japan. Phone: 272-20-8835; FAX: 272-20-8893.

Received for publication 29 August 1994 and in revised form 22 December 1994.

J. Clin. Invest.

(C) The American Society for Clinical Investigation, Inc.

$0021-9738 / 95 / 05 / 2304 / 11 \quad \$ 2.00$

Volume 95, May 1995, 2304-2314 diverse actions of activin $\mathrm{A}$ on cellular growth and differentiation in various types of cells. Activin A increases the number of gonadotrophs in anterior pituitary cultures ( 3 ) and modulates differentiation of ovarian granulosa cells (4). In addition to its action on the pituitary-gonadal axis, activin A also induces differentiation of erythroid cells $(5,6)$ and megakaryocytes (7), inhibits hepatocyte proliferation (8), modifies growth and differentiation of neuronal cells $(9,10)$, and acts as an inducer of mesoderm during development $(11,12)$. More recently, it is reported that blockade of activin receptor signaling promotes neuralization in Xenopus embryo (13).

We have shown recently that activin $A$ inhibits amylase secretion and cell proliferation in rat pancreatic acinar AR42J cells in culture (14). These cells are derived from the chemically induced rat pancreatic acinar carcinoma and are widely used for studies on the regulation of exocrine secretion. It is interesting to note that AR42J cells also possess some properties characteristic of neuroendocrine cells. For example, these cells have electrically excitable membranes (15) and express synaptophysin, a marker of neuronal cells (16). Hence, these cells are considered to be amphicrine, expressing both exocrine and neuroendocrine functions (16). Logsdon et al. (17) reported that AR42J cells become differentiated in response to dexamethasone. Thus, dexamethasone blocks cell growth, augments amylase biosynthesis, and increases the number of secretory granules. When activin $\mathrm{A}$ is added together with dexamethasone, the action of dexamethasone is attenuated: Activin A blocks dexamethasone-induced elevation of amylase content, and secretory granules disappear in activin-treated cells (14). It is noteworthy that when activin A alone is added, it completely blocks proliferation of AR42J cells, and amylase content becomes undetectable. This raises the possibility that activin A induces differentiation to a direction different from that induced by dexamethasone. Given that AR42J cells are amphicrine cells and that activin $\mathrm{A}$ is a modulator of differentiation in a variety of cells, including endocrine and neuronal cells (13), it is interesting to determine whether or not activin A affects the neuroendocrine property of AR42J cells. In the present study, we examined the effect of activin A on the morphology and function of AR42J cells. We report here that activin A converts AR42J cells into neuronlike cells.

\section{Methods}

Cell culture. AR42J cells provided by Professor Toshiyuki Takeuchi (Institute for Molecular and Cellular Regulation, Gunma University, Maebashi, Japan) were maintained in DME containing $20 \mathrm{mM}$ Hepes/ $\mathrm{NaOH}$ (pH 7.4), $5 \mathrm{mM} \mathrm{NaHCO}$, penicillin, streptomycin, and $10 \%$ FCS. Since commercially available FCS contains various amounts of activin A depending upon the lot (up to $2 \mathrm{nM}$ ), we checked the bioactivity of activin (5) in various lots of FCS and used activin-free serum 
(Flow Laboratories, North Ryde, Australia) in this study. For all experiments, cells were plated at a density of $4 \times 10^{5}$ cells $/ \mathrm{ml}$ with or without $4 \mathrm{nM}$ activin A. PLC/PRF/5 cells, a human hepatoma cell line (18), were supplied by the Foundation for Promotion of Cancer Research (Tokyo, Japan) and cultured as described above.

Antibodies. The neurofilaments were prepared from rat brain and purified with hydroxyapatite gel and DE-52 column chromatography as described by Liem and Hutchinson (19). Purified 160-kD neurofilament $(\mathrm{NF})^{1}$ protein was mixed with CFA and injected into rabbits. The rabbits received three booster shots of $160-\mathrm{kD}$ NF protein mixed with incomplete Freund's adjuvant at 14-d intervals. On the third day after the third booster, the rabbits were bled, and this serum was affinitypurified using a 160-kD neurofilament protein-bound triopropyl Sepharose 6B affinity column (Sigma Chemical Co., St. Louis, MO). The affinity-purified rabbit polyclonal antibody against rat brain microtubule-associated protein 2 (MAP-2), kindly provided by Professor Yasuo Ihara (Department of Neuropathology, University of Tokyo School of Medicine, Tokyo, Japan), specifically reacts with MAP-2 and does not cross-react with other microtubule-associated proteins $(20)$. The affinity-purified rabbit polyclonal antibody against chicken $\beta$-tubulin was a gift of Professor Kuniaki Takata (Institute for Molecular and Cellular Regulation, Gunma University). Anti-human salivary amylase monoclonal antibody was purchased from Sigma Chemical Co. (St. Louis, MO). Antisynaptophysin monoclonal antibody was from DAKOPATTS (Glostrup, Denmark). Other commercially available antibodies used were tetramethylrhodamine isothiocyanate-conjugated goat antimouse IgG (Cappel Laboratories, Turnhout, Belgium), indocarbocyanine-conjugated donkey anti-rabbit IgG (Jackson ImmunoResearch Laboratories, Inc., West Grove, PA), FITC-conjugated goat anti-rabbit IgG (Cappel Laboratories), peroxidase-conjugated goat anti-rabbit IgG (Cappel Laboratories), and peroxidase-conjugated goat anti-mouse IgG (Amersham International, Little Chalfont, UK).

Immunoblotting. For immunoblotting of MAP-2 and NF, AR42J cells or rat brains were homogenized in buffer A ( $100 \mathrm{mM}$ Pipes, $\mathrm{pH}$ 6.6, $1 \mathrm{mM}$ EGTA, $1 \mathrm{mM} \mathrm{MgSO}{ }_{4}, 1 \mathrm{mM}$ PMSF, and $10 \mathrm{mg} / \mathrm{ml}$ leupeptin). The homogenate was centrifuged at $180,000 \mathrm{~g}$ for $90 \mathrm{~min}$ at $2^{\circ} \mathrm{C}$. The resulting crude extracts were fractionated on $6 \%$ SDS-polyacrylamide gels according to the method of Laemmli (21) and electrophoretically transferred to Immobilon (Millipore Corp., Bedford, MA). For immunoblotting of synaptophysin, crude extracts of activin A-treated and untreated cells were prepared by the method of Drubin et al. (22). Protein concentration was determined by the method of Lowry et al. (23). The same amount of protein $(90 \mu \mathrm{g})$ was applied to each lane of $10 \%$ SDS-polyacrylamide gels and fractionated and transferred to Immobilon as described above.

Immunofluorescence microscopy. Cells were cultured on noncoated glass coverslips at a cell density described above. Cells were fixed with $3 \%$ paraformaldehyde in PBS, treated with $0.1 \%$ (vol/vol) Triton X100 in PBS for $5 \mathrm{~min}$, and incubated sequentially with Blocking Ace (Morinaga, Tokyo, Japan), first antibody, and indocarbocyanine-conjugated donkey anti-rabbit IgG or tetramethylrhodamine isothiocyanateconjugated goat anti-mouse IgG. The cells were examined with a microscope (Axiophoto, Carl Zeiss, Inc., Thornwood, NY). For double labeling experiments with both antiamylase mouse monoclonal antibody and anti-NF rabbit polyclonal antibody, tetramethylrhodamine isothiocyanate-conjugated anti-mouse IgG or FITC-conjugated anti-rabbit IgG was used as a second antibody.

For extraction of soluble protein before staining, cells were incubated with $0.1 \%$ Triton X-100 and $10 \mu \mathrm{M}$ Taxol in PHEM buffer (50 $\mathrm{mM}$ Pipes, pH 6.8, $50 \mathrm{mM}$ Hepes, $1 \mathrm{mM}$ EGTA, and $1 \mathrm{mM} \mathrm{MgCl}_{2}$ ),

1. Abbreviations used in this paper: $\left[\mathrm{Ca}^{2+}\right]_{c}$, cytoplasmic free calcium concentration; CICR, calcium-induced calcium release; $K_{A T P}$ channel, ATP-sensitive potassium channel; MAP, microtubule-associated protein; NF, neurofilament; RT-PCR, reverse transcription PCR; VDCC, voltage-dependent calcium channel. fixed with 3\% paraformaldehyde in PHEM buffer, and incubated sequentially with antibodies as described above.

Electron microscopy. Cells were fixed with $2.5 \%$ glutaraldehyde in $0.1 \mathrm{M}$ cacodylated buffer ( $\mathrm{pH} 7.4$ ) for $1 \mathrm{~h}$ at $4^{\circ} \mathrm{C}$, washed with the same buffer, and postfixed in $1 \%$ osmium teroxide in the same buffer reduced with $1.5 \%$ potassium ferrocyanide. After further washes in the same buffer followed by collection into a microspin tube, the cells were mixed with warm liquid agarose to prepare blocks of agarose-embedded cells. The agarose blocks were dehydrated with an ethanol series, filtrated with propylene oxide, and embedded in an Epon/Araldite (Nisshin EM Inc., Tokyo, Japan) mixture. Ultrathin sections were cut with a diamond knife on a microtome (Ultracut-E; Reichert-Jung, Vienna, Austria) and mounted on nickel grids. The grids were stained with uranyl acetate and lead citrate and observed with an electron microscope (JEM 1200 EX; Japan Electronic Optics, Tokyo, Japan) at $80 \mathrm{kV}$ accelerating potential. For immunoelectron microscopy, extracted cells as described above were fixed with $2 \%$ paraformaldehyde and $0.1 \%$ glutaraldehyde. After washing with $50 \mathrm{mM}$ PBS glycine and blocking with $5 \%$ BSA, the cells were incubated with anti-MAP-2 antibody, followed by incubation with $1 \mathrm{~nm}$ gold-conjugated goat anti-rabbit IgG (Nanoprobes Inc., Stony Brook, NY). After extensive washing with PBS, the cells were again fixed with $2 \%$ paraformaldehyde and $1 \%$ glutaraldehyde in $10 \mathrm{mM}$ phosphate buffer ( $\mathrm{pH} 7.4$ ), followed by silver intensifying with silver acetate solution as previously described by Murata et al. (24). After immersing in $0.05 \% \mathrm{HAuCl}_{4}$ solution and extensive washing, the cells were postfixed with $1 \% \mathrm{O}_{5} \mathrm{O}_{4}$ solution in $0.1 \mathrm{M}$ phosphate buffer ( $\mathrm{pH}$ 7.4) and processed for preparing routine electron microscopic specimen. The ultrathin sections were observed as described above.

Analysis of mRNA for neuroendocrine/ $\beta$ cell-type voltage-dependent calcium channel $\alpha_{1}$ subunit by competitive reverse transcription $P C R$. To detect mRNA for the $\alpha_{1}$ subunit of neuroendocrine/ $\beta$ celltype voltage-dependent calcium channel (VDCC) and to compare its level between activin A-treated and untreated cells, we used competitive reverse transcription PCR (RT-PCR) described by Iwashima et al. (25). In this method, a DNA competitor, which was synthesized by deleting 42 bp from the neuroendocrine/ $\beta$ cell-type VDCC $\alpha_{1}$ subunit cDNA by site-directed mutagenesis and which had the same primer sequences as the neuroendocrine/ $\beta$ cell-type VDCC $\alpha_{1}$ subunit, was used as an internal standard. This competitor was kindly provided by Dr. Jun Takeda (University of Chicago, Chicago, IL). We used this competitor as an internal standard, and we could distinguish the competitor from the authentic reverse transcript because of the difference in sizes. The difference in efficiency of PCR between reaction tubes was corrected. Double-stranded cDNA of AR42J cells was synthesized from poly (A) RNA obtained by using the Quick Prep Kit (Pharmacia LKB Biotechnology, Inc., Piscataway, NJ). Rat islet cDNA library, kindly provided by Professor Kazuhiko Tatemoto (Institute for Molecular and Cellular Regulation, Gunma University), was used as a control template. Oligonucleotide primers were designed on the basis of neuroendocrine/ $\beta$ cell-type VDCC $\alpha_{1}$-subunit cDNA sequence (26). The sense and antisense primers were $5^{\prime}$-ATTGCTGTAGACAATTTGGCT-3' and 5'-AGCAGGAACCTCAGGCTCGT-3', respectively. The sizes of PCR products from neuroendocrine/ $\beta$ cell-type VDCC $\alpha_{1}$ subunit and its competitor were $276 \mathrm{bp}$ and $234 \mathrm{bp}$, respectively. The reactions were conducted in a DNA Thermal Cycler (Perkin-Elmer Corp., Norwalk, CT) with the following cycle of conditions: denaturation at $94^{\circ} \mathrm{C}$ for 1 min, annealing at $58^{\circ} \mathrm{C}$ for $1 \mathrm{~min}$, and extension at $72^{\circ} \mathrm{C}$ for $1 \mathrm{~min}$. The number of cycles was 30 . The products were separated on an $8 \%$ polyacrylamide gel and visualized with ethidium bromide.

Measurement of cytoplasmic free calcium concentration $\left(\left[\mathrm{Ca}^{2+}\right]_{c}\right)$. Cells were grown on a glass coverslip and treated with or without activin A. Cells were then loaded with a calcium-sensitive fluorescent dye, fura-2, by incubating with $2 \mu \mathrm{M}$ fura-2/acetoxymethylester for $30 \mathrm{~min}$ at room temperature. The fura-2-loaded cells were applied on a fluorescent microscope, and fluorescence from a single cell was monitored as described previously (27). $\left[\mathrm{Ca}^{2+}\right]_{c}$ was estimated assuming an even distribution of free calcium in cytosol (27). 

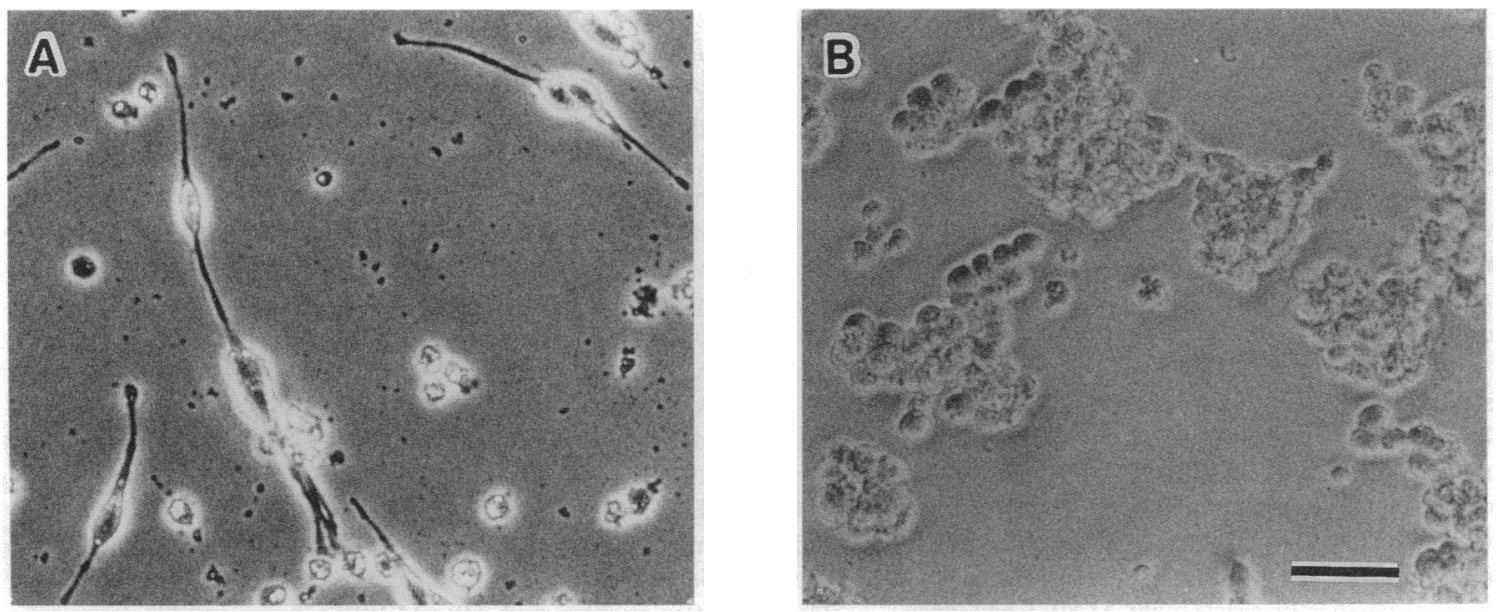

Figure 1. Phase-contrast micrographs of AR42J cells. AR42J cells were incubated in DME containing $10 \%$ FCS $(A)$ with or $(B)$ without 4 nM activin $\mathrm{A}$ for $10 \mathrm{~d}$, and phase-contrast micrographs were taken. Bar, $30 \mu \mathrm{m}$.

Measurement of activity of ATP-sensitive potassium channel and $V D C C$. Single channel recording of ATP-sensitive potassium channel ( $\mathrm{K}_{\mathrm{ATP}}$ channel) was performed by an inside-out configuration of the patch clamp technique (28). The pipette solution contained $150 \mathrm{mM}$ $\mathrm{NaCl}, 5 \mathrm{mM} \mathrm{KCl}, 1 \mathrm{mM} \mathrm{MgCl}, 2 \mathrm{mM} \mathrm{CaCl}$, and $10 \mathrm{mM}$ Hepes/ $\mathrm{NaOH}$ ( $\mathrm{pH} 7.4)$. High resolution membrane currents were recorded using a patch clamp amplifier (EPC-9; HEKE, Lambrecht, Germany) controlled by the "E9 screen" software on an Atari (Sunnyvale, CA) computer. Membrane potential was clamped at $0 \mathrm{mV}$. $\mathrm{K}^{+}$channel openings were seen as inward currents and conventionally displayed as downward deflections in the records. The bath solution contained $150 \mathrm{mM}$ $\mathrm{KCl}, 1 \mathrm{mM} \mathrm{MgCl}$, $5 \mathrm{mM}$ EGTA, and $10 \mathrm{mM}$ Hepes/KOH (pH 7.2).

VDCC was measured by the perforated mode of patch clamp technique (29). The extracellular solution contained $115 \mathrm{mM} \mathrm{NaCl}, 5 \mathrm{mM}$ $\mathrm{CsCl}, 1 \mathrm{mM} \mathrm{MgCl}, 10 \mathrm{mM} \mathrm{BaCl}, 10 \mathrm{mM}$ tetraethylammonium chloride, $2.7 \mathrm{mM}$ glucose, and $10 \mathrm{mM}$ Hepes $/ \mathrm{NaOH}(\mathrm{pH} 7.4)$. The pipette solution contained $95 \mathrm{mM}$ cesium aspartate, $40 \mathrm{mM} \mathrm{CsCl}, 5 \mathrm{mM} \mathrm{NaCl}$, $1 \mathrm{mM} \mathrm{MgCl}$, and $10 \mathrm{mM}$ Hepes/NaOH ( $\mathrm{pH} 7.2$ ).

\section{Results}

Process outgrowth of AR42J cells in response to activin A. We studied the effect of activin A on rat pancreatic acinar AR42J cells. After cells were grown in activin A-free medium, $4 \mathrm{nM}$ activin A was added. At this concentration, DNA synthesis in AR42J cells was completely blocked (14). AR42J cells extended cytoplasmic processes within $72 \mathrm{~h}$ of the activin A treatment, and their processes were elongated up until 10-12 d after the addition of activin A. Many of these processes were several cell diameters in length and growth conelike structures were observed in all of them (Fig. $1 \mathrm{~A}$ ). In the absence of activin A, cells continued proliferation and formed aggregation (Fig. $1 B$ ). The process outgrowth of AR42J was specific to activin $A$ and was not observed by the addition of TGF- $\beta_{1}$ or nerve growth factor (data not shown).

Characterization of antibodies and immunoblotting of neurofilament and MAP-2 in AR42J cells. To elucidate that these extended processes were similar to those of cultured neurons, we analyzed the changes in cytoskeletal architecture. First, we investigated the existence of neuron-specific cytoskeletal proteins by immunoblotting using antibodies directed against the $160-\mathrm{kD}$ subunit of rat NF, a neuron-specific intermediate filament protein, and MAP-2, a neuron-specific high molecular microtubule-associated protein. Fig. 2 shows an immunoblotting of crude extracts of rat brain and AR42J cells by affinitypurified polyclonal antibodies against NF and MAP-2. The polyclonal antibodies to NF and MAP-2 strongly recognized the band of NF $160-\mathrm{kD}$ subunit and MAP-2 in rat brain crude extract, respectively. These polyclonal antibodies also recognized both NF and MAP-2 in crude extract of AR42J cells. Treatment with activin A did not change the content of NF and MAP-2 in AR42J cells (data not shown).

Conversion of AR42J cells from amylase-secreting cells to neuronlike cells. To demonstrate that activin A induced differentiation of AR42J cells to neuronlike cells, we performed double immunofluorescence staining with antiamylase and NF anti-

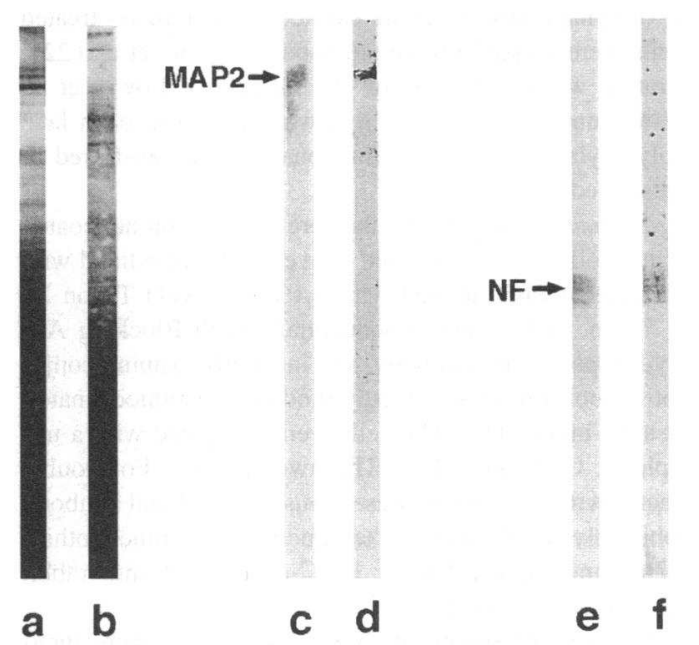

Figure 2. Characterization of anti-NF and anti-MAP-2 antibodies and existence of NF and MAP-2 in AR42J cells. Crude extract of rat brain (lanes $a, c$, and $e$ ) and of naive AR42J cells (lanes $b, d$, and $f$ ) were fractionated on 6\% SDS-polyacrylamide gels. Lanes $a$ and $b$ are stained with Coomassie briliant blue. Lanes $c$ and $d$ are immunoblot staining with anti-MAP-2 antibody, and lanes $e$ and $f$ are with anti-NF antibody. Anti-MAP-2 antibody (lane $c$ ) and anti-NF antibody (lane $e$ ) showed specific staining against MAP-2 and NF of rat brain, respectively, and showed the existence of MAP-2 (lane $d$ ) and NF (lane $f$ ) in AR42J cells. 

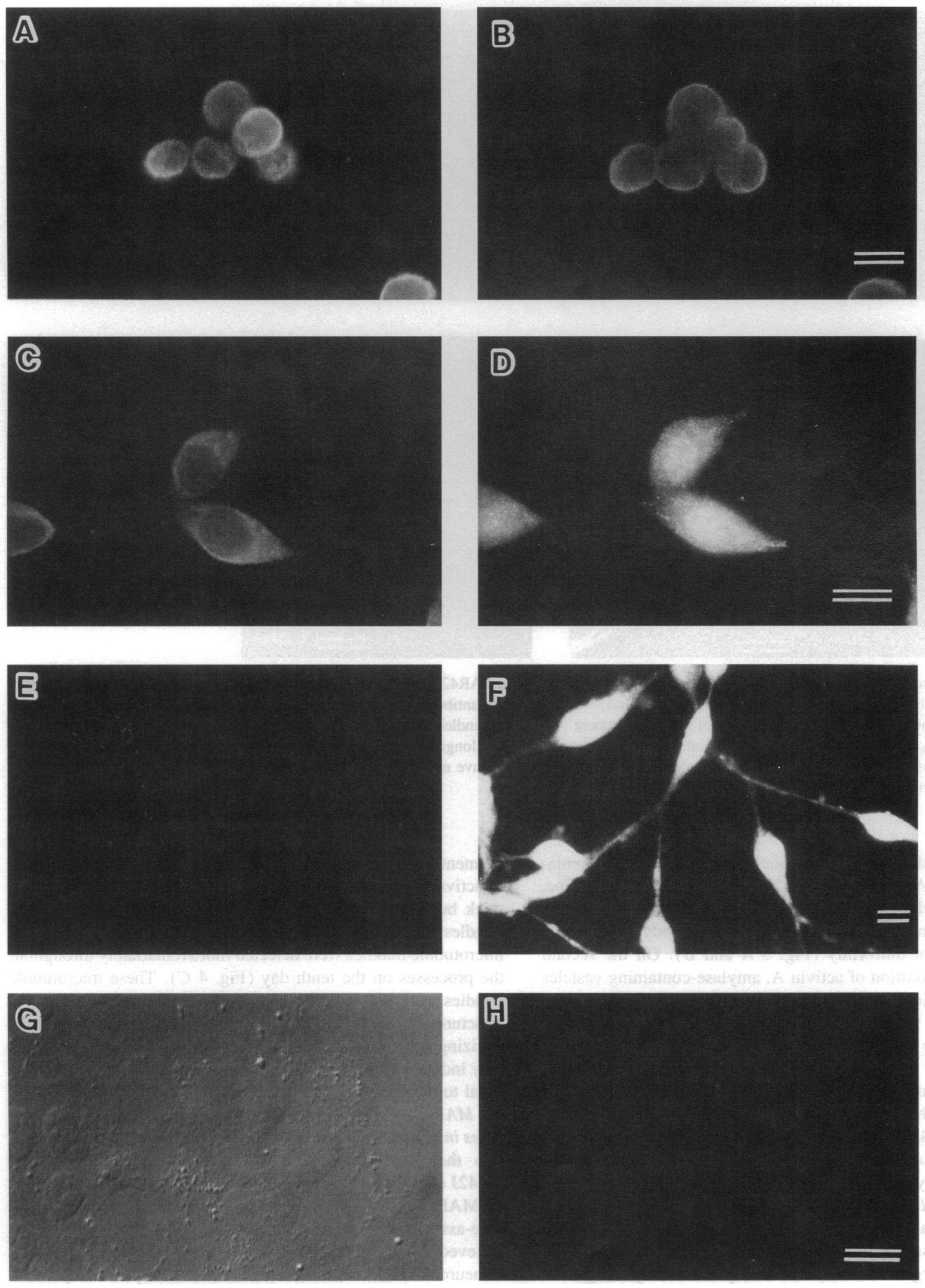

Figure 3. Immunofluorescence micrographs of activin A-treated and untreated AR42J cells. AR42J cells were incubated in DME containing 10\% FCS and $4 \mathrm{nM}$ activin A for $0(A, B), 2(C, D)$, and $10(E, F)$ d. Cells were double-stained with antiamylase $(A, C$, and $E)$ and anti-NF $(B, D$, and $F$ ) antibodies. Negative controls with PLC/PRF/5 cells stained with anti-NF antibody showed no staining $(H)$. $G$ shows its Nomarski image of the same area as shown in $H$. Bars, $5 \mu \mathrm{m}$. 

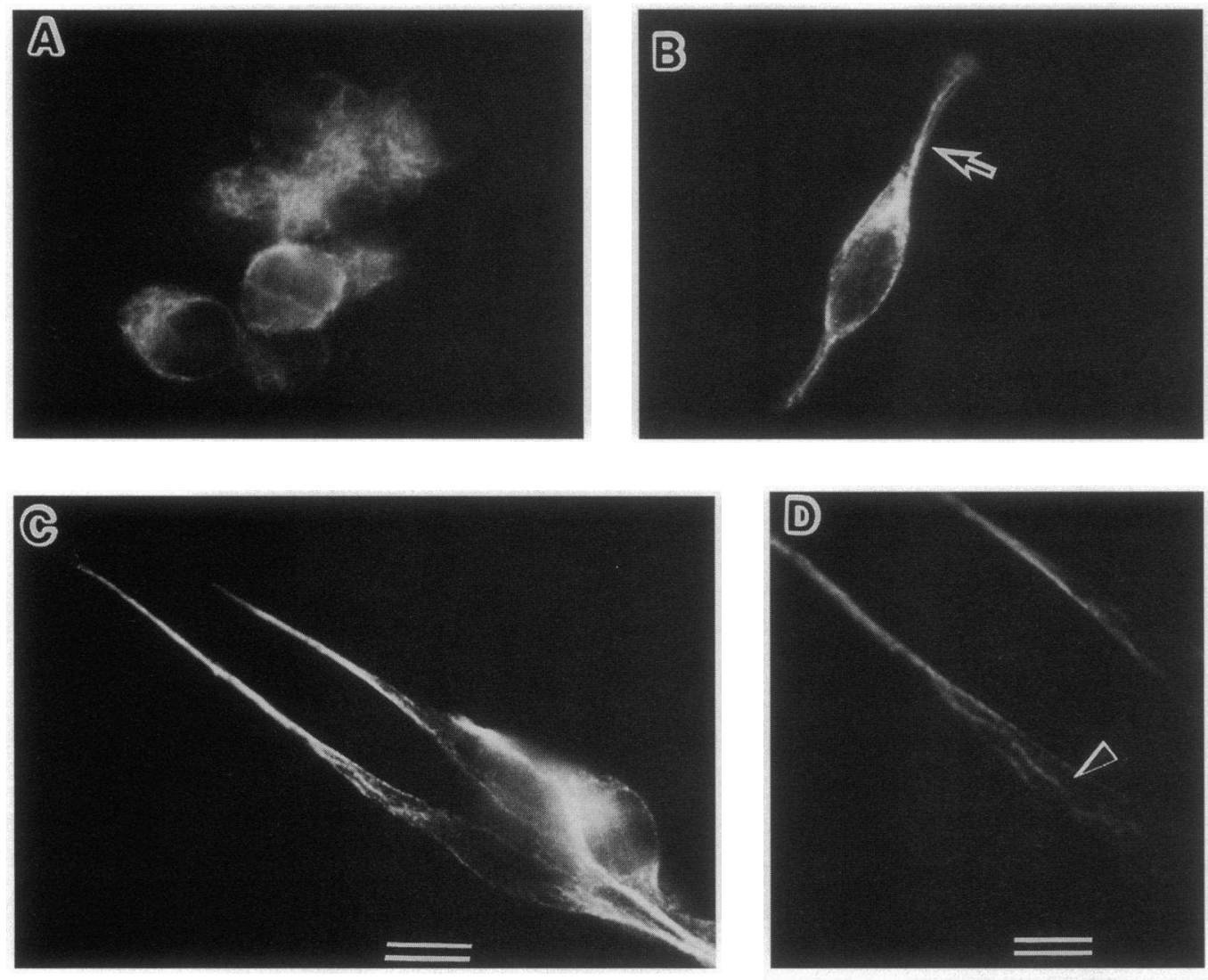

Figure 4. Immunofluorescence micrographs of activin A-treated and untreated AR42J cells using antitubulin antibody. AR42J cells were incubated in DME containing $10 \%$ FCS for $10 \mathrm{~d}$, and cells were stained with antitubulin antibody. In untreated AR42J cells $(A)$, microtubules are observed as fine filamentous network. On the third day of activin treatment $(B)$, thick bundles of microtubules are shown in extended processes (arrow). On the tenth day $(C)$, thick bundles are observed prominently throughout the elongated processes, and fine microtubule networks are hardly seen in the cell bodies. $D$ is a high magnification observation of $C$. Thick bundles have no distinct nucleating structure $(D$, arrow head $)$. Bars: $(A-C)$ $5 \mu \mathrm{m} ;(D) 2 \mu \mathrm{m}$.

bodies. Fig. 3 depicts the time course of AR42J cell differentiation. Activin A-untreated AR42J cells were round in shape, and their amylase-containing secretory vesicles were stained with the antiamylase antibody. Anti-NF antibody also stained their cytoplasm uniformly (Fig. $3 A$ and $B$ ). On the second day after the addition of activin $A$, amylase-containing vesicles decreased moderately, and cells started extending multiple processes, which were labeled with anti-NF antibody (Fig. 3, C and $D)$. On the tenth day, no staining of amylase was discernible (Fig. $3 E$ ), in contrast to the strong staining of the extended processes by anti-NF antibody (Fig. $3 F$ ). These data document that activin inhibits amylase synthesis in AR42J cells and induces neuronlike process formation containing NF organization. Thus, these results suggest that activin A may induce differentiation from amylase-secreting cells to neuronlike cells.

Microtubule organization in activin A-treated AR42J cells. To further characterize the cytoskeletal organization in cytoplasmic processes induced by activin $\mathrm{A}$, we studied changes in microtubule organization by immunocytochemistry using antitubulin antibody. In nonneuronal cultured cells, microtubules were observed as fine filamentous networks emanating from a discrete centralized nucleating structure such as the centrosome. However, in neurons, microtubules formed thick bundles in neurites, and they did not have any discrete origins $(30,31)$. In naive AR42J cells, microtubules radiated and formed fine filamentous networks (Fig. $4 \mathrm{~A}$ ). It is interesting to note that, in activin A-treated AR42J cells, microtubules tended to form thick bundles. On the third day of activin A treatment, thick bundles were observed in extended process (Fig. $4 B$ ), and microtubule bundles were detected more remarkably throughout the processes on the tenth day (Fig. $4 \mathrm{C}$ ). These microtubule bundles were not visibly associated with any other cytological structures in the cell body that might serve as microtubule organizing centers (Fig. $4 \mathrm{D}$ ). These data suggest that activin A may induce a change in microtubule organization from nonneuronal to neuronal.

MAP-2 as a component of cross-bridges between microtubules in activin $A$-induced processes. To further gain an insight into the cytoskeletal similarity between activin A-treated AR42J cells and authentic neurons, we studied the participation of MAP-2 in activin-induced neuritelike processes. Microtubule-associated proteins such as MAP-1, MAP-2, and tau are believed to contribute to the highly differentiated morphology of neurons and to maintain neurites structurally as components of cross-bridges between microtubules (32). MAP-2 in particular is neuron specific and abundant in dendrites (33). The AR42J cells contained MAP- 2 in the cytoplasm before differentiation and in the processes formed after the treatment with activin A (Fig. 5, $A$ and $C$ ). To further elucidate the contribution of MAP-2 to neuronlike differentiation, light and electron mi- 

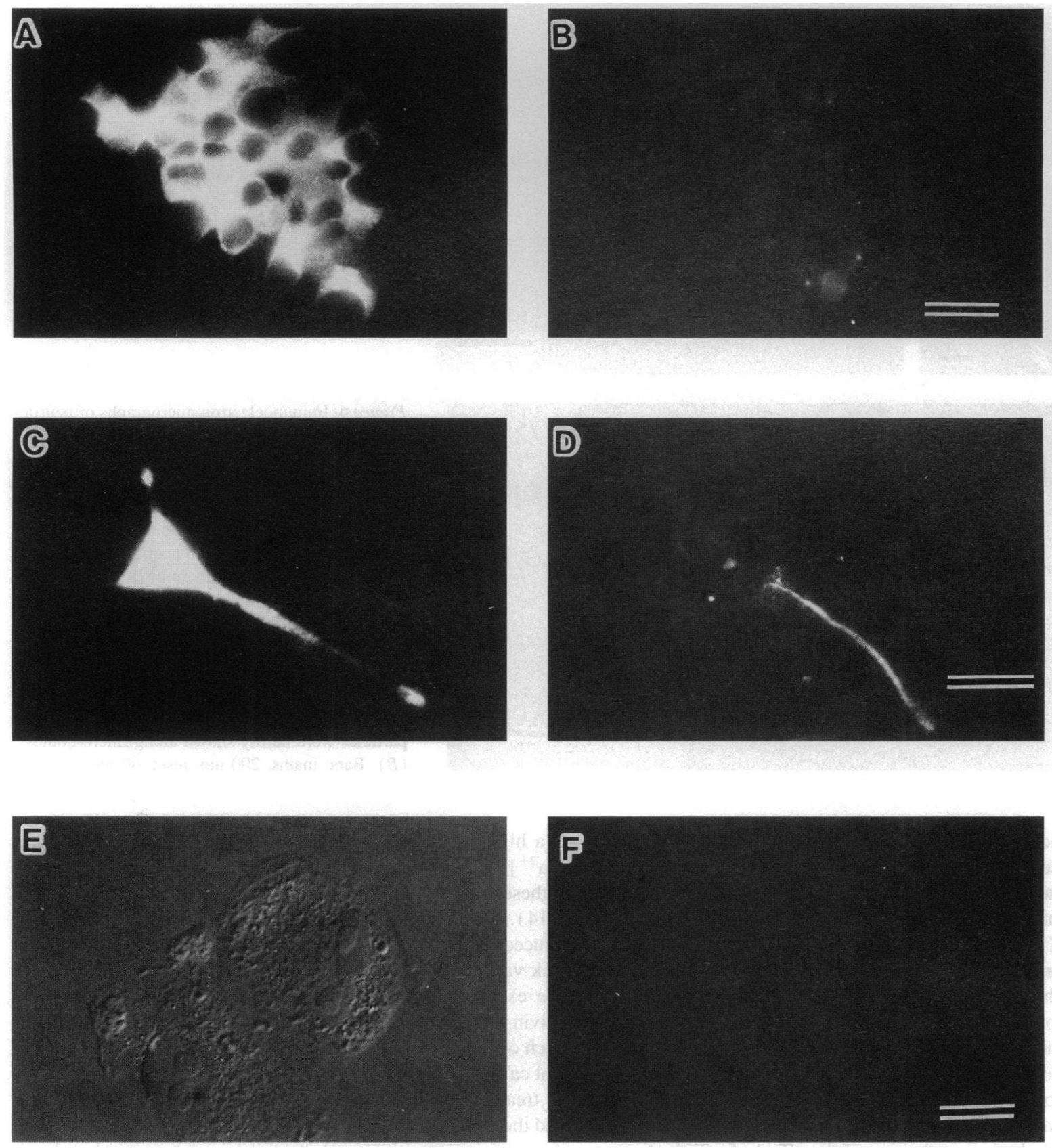

Figure 5. Immunofluorescence micrographs of activin A-treated and untreated AR42J cells using anti-MAP-2 antibody. AR42J cells were incubated in DME containing $10 \%$ FCS and $4 \mathrm{nM}$ activin A for $10 \mathrm{~d}$. Cells were then stained with anti-MAP-2 antibody before and after permeabilization of the plasma membrane as described in Methods. In untreated cells, cytoplasma are stained diffusely $(A)$. After extraction of soluble protein, cells are hardly stained $(B)$. In activin A-treated cells, both cell body and processes are stained $(C)$. After extraction of soluble protein, cell body does not give off a signal and process is stained as a thick line. Negative controls with PLC/PRF/5 cells stained with anti-MAP-2 antibody showed no staining $(F) . E$ shows its Nomarski image of the same area as in $F$. Bars, $10 \mu \mathrm{m}$.

croscopic immunocytochemistry was performed after permeabilization of the cell membrane to wash out soluble proteins. Fig. 5, $B$ and $D$, shows indirect immunofluorescence of activinuntreated and -treated AR42J cells for MAP-2 after permeabilization. In activin A-untreated cells, the round cells showed no immunoreactivity (Fig. 5 B). In activin-treated cells, no signal was observed in the cell bodies, but linear thick bundlelike staining was observed in their processes (Fig. $5 \mathrm{D}$ ). This suggests that MAP-2 may exist solely in soluble form in activin
A-untreated AR42J cells, and, after treatment with activin A, a certain amount of MAP- 2 may organize Triton X-100-insoluble bundles of microtubules in neuritelike processes.

To elucidate the participation of MAP-2 within cytoskeletons of the neuritelike processes, we labeled the activin-treated and untreated AR42J cells extracted with Triton X-100 by using antiMAP-2 antibody followed by immunogold staining. Fig. $6 \mathrm{~A}$ shows an activin-treated AR42J cell process labeled with antiMAP-2 antibody. Microtubules formed many parallel arrays, sug- 

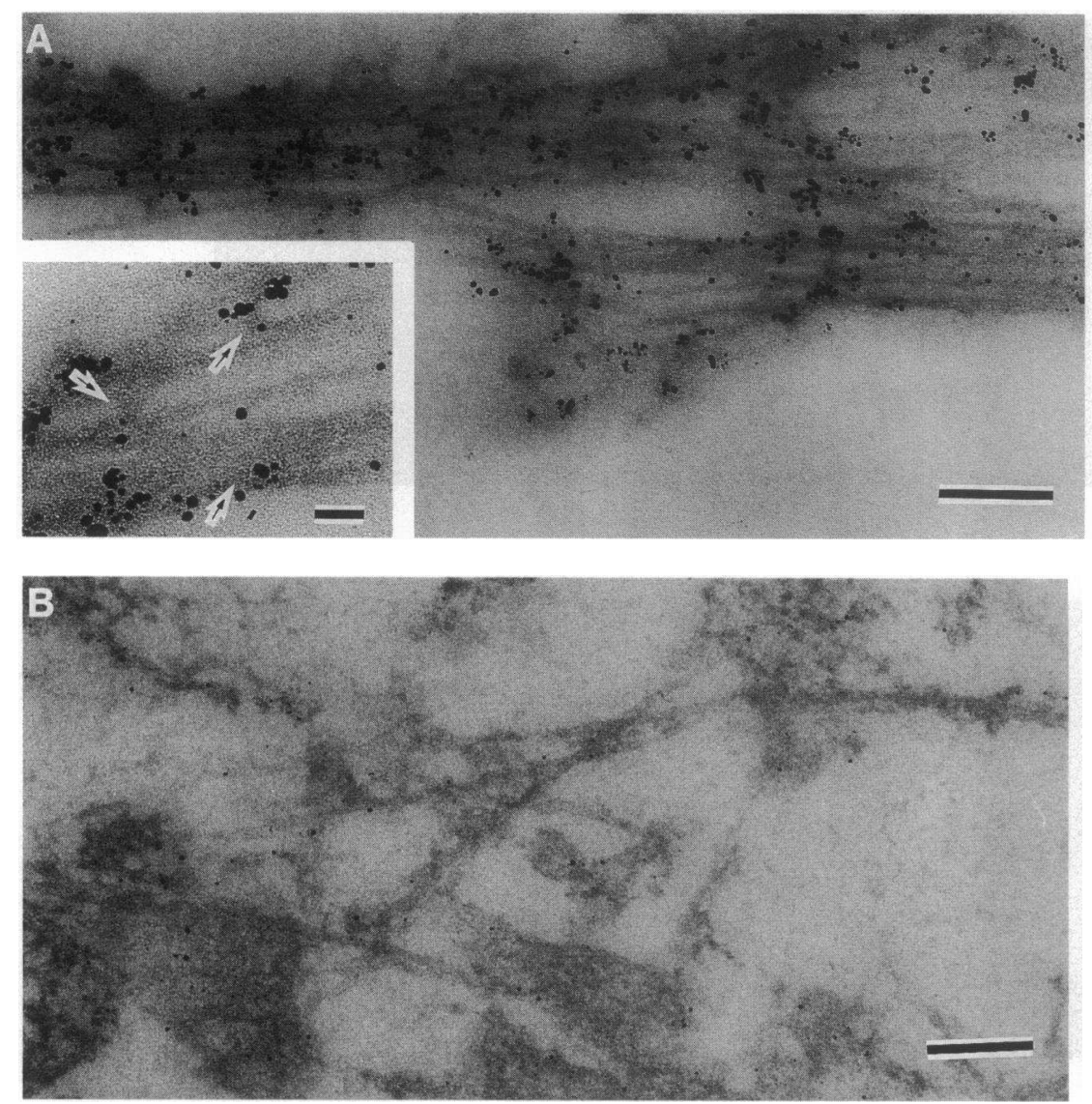

Figure 6. Immunoelectron micrographs of neuritelike process in activin A-treated cells and cytoplasm of untreated cells using anti-MAP- 2 antibody. AR42J cells were treated with or without 4 $\mathrm{nM}$ activin $\mathrm{A}$ for $10 \mathrm{~d}$, and immunoelectron micrographs using anti-MAP-2 antibody were obtained as described in Methods. In neuritelike process of activin A-treated cells, microtubules formed bundles and immunoreactivity of MAP-2 were studded between the parallel microtubules $(A)$. In higher magnification observation ( $A$, inset), immunogold particles were shown on cross-bridges between microtubules (arrows). In activin-untreated cells, microtubules never formed bundles and immunogold particles were hardly shown along microtubules $(B)$. Bars: mains, $200 \mathrm{~nm}$, inset, $40 \mathrm{~nm}$. gesting that microtubules formed bundles, and gold particles were studded between the parallel microtubules. A higher magnification view shows more clearly the localization of most particles on the projecting portions of filamentous fuzzy materials between microtubules (Fig. $6 \mathrm{~A}$, inset). In naive AR42J cells, microtubules never formed bundles and gold particles were hardly seen along microtubules (Fig. $6 \mathrm{~B}$ ). These data suggest that MAP-2 serves as a component of cross-bridges between microtubules in activin-induced processes of AR42J cells. This cytoskeletal architecture closely resembles that of authentic neurons as previously described by Hirokawa et al. (34).

Effect of activin A on expression of synaptophysin. To expand the morphological evaluation of the effect of activin A on AR42J cells, we examined the secretory vesicle formation by electron microscopy. In activin-treated cells, many small vesicles were observed in the cytoplasm (Fig. $7 A$ ). In untreated cells, however, such vesicles were rarely observed (Fig. 7 B). Immunofluorescent microscopy revealed that the number of synaptophysin-containing vesicles was markedly increased in activin-treated cells (Fig. 8, $A$ and $B$ ), and such synaptophysincontaining vesicles were detected in the extended process of activin-treated cells (Fig. $8 \mathrm{~A}$ ). The increase in synaptophysin, a marker of synaptic vesicles, was also confirmed by immunoblotting (Fig. $8 \mathrm{C}$ ). Immunohistochemically, neither glucagon nor insulin was detected in activin-treated cells.

Changes in ionic channels expressed in AR42J cells in response to activin $A$. To determine functional alterations induced by activin $A$, we investigated the changes in ionic channels expressed in AR42J cells. Previous studies demonstrated that VDCC was expressed in these cells (15). As shown in Fig. 9
$A$, a high concentration of potassium induced an elevation of $\left[\mathrm{Ca}^{2+}\right]_{c}$, an observation consistent with the existence of VDCC in these cells. The peak value of $\left[\mathrm{Ca}^{2+}\right]_{\mathrm{c}}$ was $230 \pm 56 \mathrm{nM}(n$ $=14$ ). When cells were treated with activin A, the potassiuminduced rise in $\left[\mathrm{Ca}^{2+}\right]_{c}$ was markedly augmented. Thus, the peak value was $782 \pm 113 \mathrm{nM}($ mean $\pm \mathrm{SE}, n=14)$. We therefore examined voltage-dependent calcium channel current in activin-treated and untreated cells by whole-cell recording of patch clamp technique. The amplitude of L-type voltage-dependent calcium channel current was not changed significantly after the treatment with activin A (data not shown). We then examined the effect of caffeine on $\left[\mathrm{Ca}^{2+}\right]_{c}$ to determine the existence of a caffeine-sensitive pool involved in calcium-induced calcium release (CICR). As depicted in Fig. $9 \mathrm{~B}$, caffeine induced a marked elevation of $\left[\mathrm{Ca}^{2+}\right]_{\mathrm{c}}$ in activin-treated cells, whereas $\left[\mathrm{Ca}^{2+}\right]_{c}$ was increased only slightly in untreated cells. The peak values of $\left[\mathrm{Ca}^{2+}\right]_{\mathrm{c}}$ in activin-treated and untreated cells were $812 \pm 114 \mathrm{nM}($ mean \pm SE, $n=14)$ and $182 \pm 54(n=14)$, respectively. We then analyzed subtypes of VDCC in AR42J cells. Surprisingly, activin-treated AR42J cells expressed mRNA for $\alpha_{1}$ subunit of neuroendocrine/ $\beta$ cell-type VDCC (26). Competitive RT-PCR revealed that the steady state level of mRNA for the $\alpha_{1}$ subunit of the channel was detected in activin-treated cells (Fig. 10). It is well known that pancreatic endocrine cells express $\mathrm{K}_{\mathrm{ATP}}$ channel. Antidiabetic drugs, sulfonylureas, inhibit the activity of the $\mathrm{K}_{\mathrm{ATP}}$ channel and thereby depolarize the plasma membrane, which leads to an increase in calcium entry via VDCC. To examine the possibility that AR42J cells express $\mathrm{K}_{\mathrm{ATP}}$ channel, we determined the effect of tolbutamide, a sulfonylurea agent, on $\left[\mathrm{Ca}^{2+}\right]_{\mathrm{c}}$ in a single AR42J cell. 

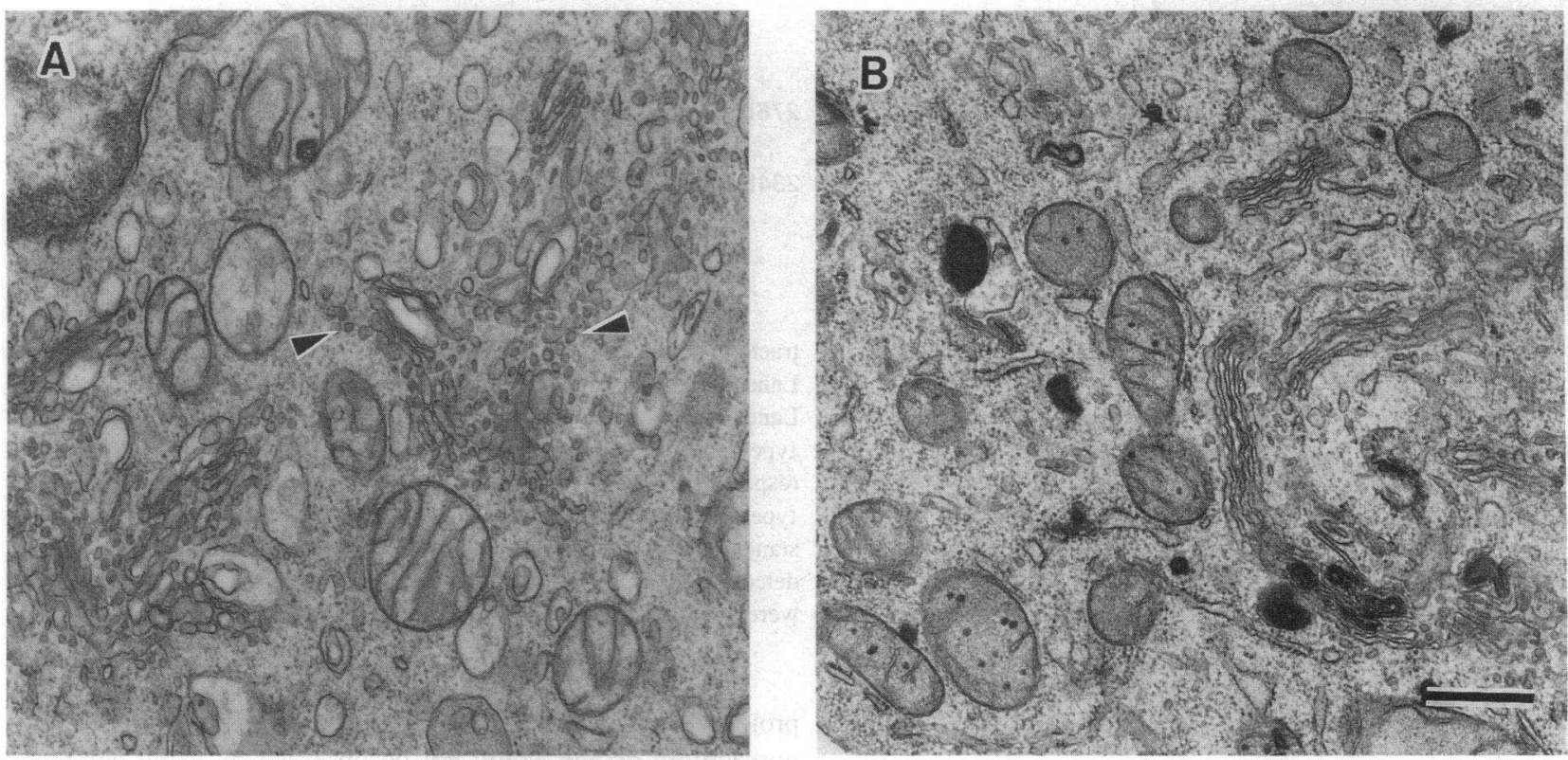

Figure 7. Electron micrographs of activin A-treated and untreated AR42J cells. AR42J cells incubated for $10 \mathrm{~d}$ with or without $4 \mathrm{nM}$ activin A were examined by conventional electron microscopy. In activin-treated cells $(A)$, many small vesicles were observed throughout the cytoplasm (arrowheads). In untreated cells $(B)$, such vesicles were not observed. Bar, $500 \mathrm{~nm}$.

As shown in Fig. 11, tolbutamide did not affect $\left[\mathrm{Ca}^{2+}\right]_{c}$ in naive AR42J cells. An elevation was observed in none of the cells tested $(n=21)$. In sharp contrast, tolbutamide induced a marked elevation of $\left[\mathrm{Ca}^{2+}\right]_{c}$ in all of the activin-treated cells tested $(n=18)$. These results suggest that $\mathrm{K}_{\mathrm{ATP}}$ channels may be expressed in activin-treated cells. To confirm this point, we measured the activity of potassium currents by single channel recording using the patch clamp technique. As depicted in Fig. 12 , burstlike openings of channels were observed in an insideout patch. Openings of at least two channels were observed in this recording, and opening of these channels was almost completely blocked by an addition of ATP in the bath. These results indicated that the currents were due to $\mathrm{K}_{\mathrm{ATP}}$ channel. $\mathrm{K}_{\mathrm{ATP}}$ channel was detected in all of the patches obtained from activin-treated cells $(n=12)$ but in none of the patches obtained from untreated cells $(n=10)$.

\section{Discussion}

The present results demonstrate that the effect of activin A on pancreatic acinar AR42J cells is to extend multiple cytoplasmic processes. We have done cytoskeletal analysis to verify these processes to be neuritelike, whether or not these processes have the distinctive morphology of highly polarized neurites, den-


Figure 8. Immunofluorescence microscopy and immunoblotting of activin A-treated and untreated AR42J cells using antisynaptophysin antibody. AR42J cells were incubated for $10 \mathrm{~d}$ with or without $4 \mathrm{nM}$ activin A. In activin-treated cells $(A)$, strong signals of synaptophysin-forming vesiclelike dots were seen throughout the cytoplasm. Those signals were detected even in some extended processes (arrow). In untreated cells $(B)$, only weak signals were detected in the cytoplasm (arrowheads). Bar, $5 \mu \mathrm{m}$. Immunoblot analysis $(C)$ of crude extracts of rat brain (lane $a$ ), activin A-treated (lane $b$ ), and untreated (lane $c$ ) AR42J cells showed a remarkable increase in synaptophysin induced by activin A. The same amount of protein $(90 \mu \mathrm{g})$ was applied to lanes $b$ and $c$. 

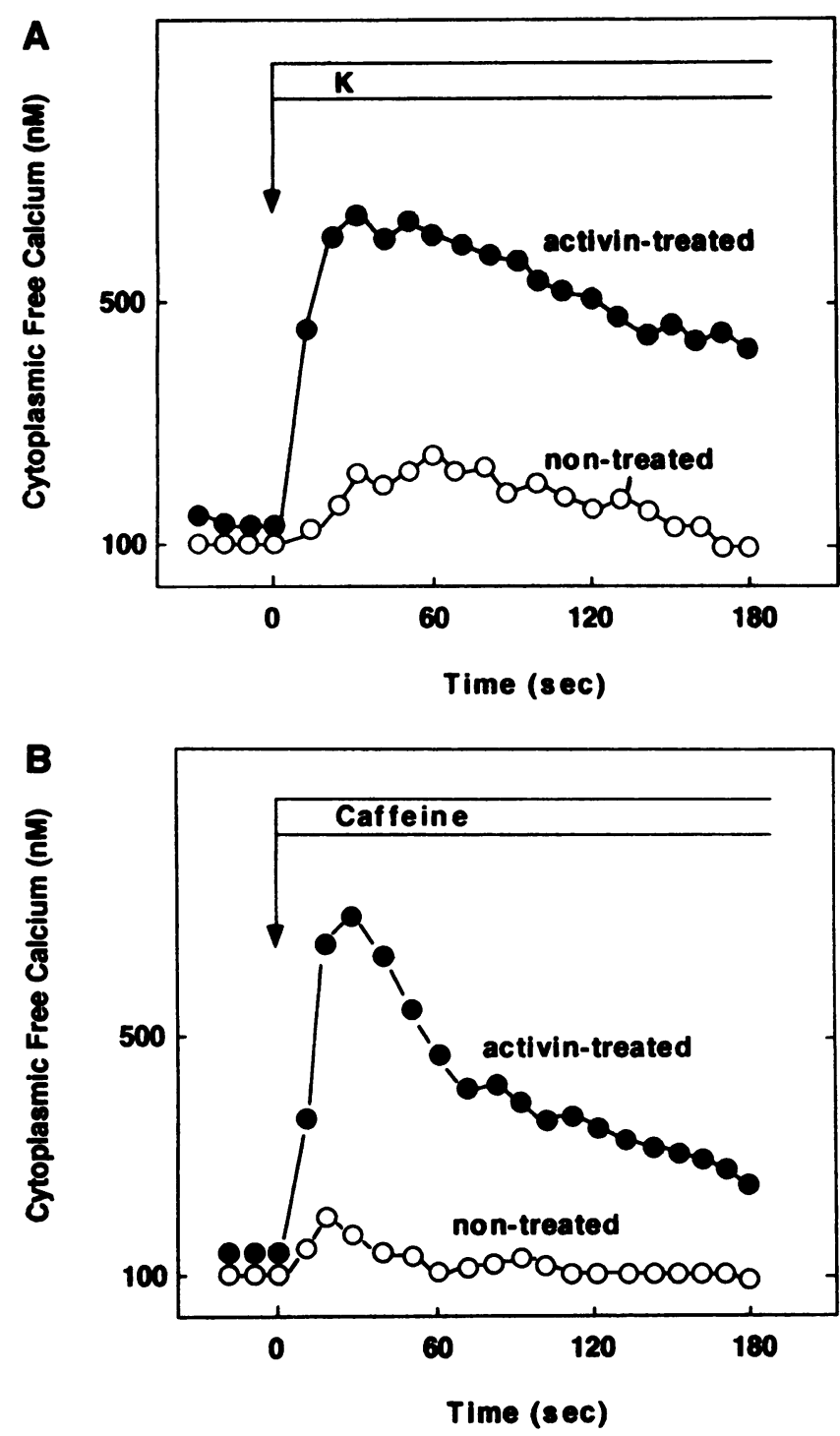

Figure 9. Effect of depolarizing concentration of potassium and caffeine on cytoplasmic free calcium concentration in activin $\mathrm{A}$-treated and untreated AR42J cells. Single cell recording of $\left[\mathrm{Ca}^{2+}\right]_{c}$ was done using fura-2 as described in Methods. AR42J cells were incubated for $10 \mathrm{~d}$ with or without $4 \mathrm{nM}$ activin A. (A) Activin A-treated ( $\bullet$ ) and untreated (O) cells were stimulated by $40 \mathrm{mM} \mathrm{KCl}$, and changes in $\left[\mathrm{Ca}^{2+}\right]_{c}$ were monitored. $(B)$ Activin A-treated $(\bullet)$ and untreated $(O)$ cells were stimulated by $1 \mathrm{mM}$ caffeine. Representative responses are presented.

drites, and axons (35). In neurites, microtubules form thick bundles that do not emanate from a microtubule organizing center as in nonneuronal cells (30). Neuron-specific microtubule-associated proteins such as MAP-1, MAP-2, and tau contribute to the microtubule organization and neurite maintenance by forming cross-bridges between microtubules $(32,33)$. Neurofilaments, which are neuron-specific intermediate filaments composed of distinct subunit proteins, are another major framework of mammalian neurons $(36,37)$. In AR42J cells, $160-\mathrm{kD}$ subunit of NFs and MAP-2 exists in the cytoplasm before the activin A treatment. Since AR42J cells demonstrate neuroendocrine property, containing small vesicles with synaptophysin (16) and molecular devices for uptake and release of $\gamma$-aminobutylic acid, the expression of these neuron-specific cytoskeletal

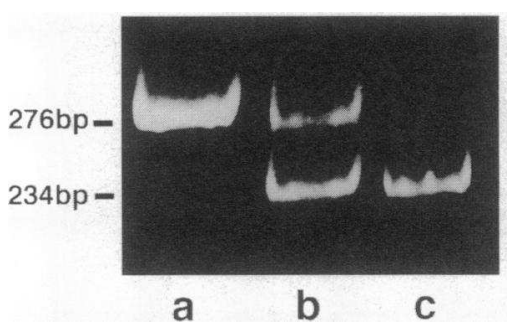

Figure 10. Competitive RT-PCR analysis of mRNA for neuroendocrine/ $\beta$ cell-type voltage-dependent calcium channel $\alpha_{1}$ subunit. AR42J cells were incubated for $10 \mathrm{~d}$ with or without $4 \mathrm{nM}$ activin $\mathrm{A}$ and mRNA was ex-

tracted. Competitive RT-PCR was performed as described in Methods. Lane $a$ is a positive control using rat islet cDNA library as a template. Lanes $b$ and $c$ show expression of mRNA for neuroendocrine/ $\beta$ celltype VDCC $\alpha_{1}$ subunit in activin A-treated and untreated AR42J cells, respectively. Bands of $276 \mathrm{bp}$ are products of neuroendocrine/ $\beta$ celltype VDCC $\alpha_{1}$ subunit, and the bands of 234 bp were from internal standard. Note that neuroendocrine/ $\beta$ cell-type VDCC product was detected only in activin-treated cells, whereas internal standard products were equally observed in activin-treated and untreated cells.

proteins is not surprising. In a previous report, however, immunoreactivity of NFs could not be observed by using commercially available anti-NF antibodies in immunocytochemistry (16). This may be due to the difference in the sensitivity of the antibodies used in their experiment and ours. Note that we show the existence of $160-\mathrm{kD}$ subunit of NF by immunoblotting as well. After treatment with activin A, AR42J cells begin to extend cytoplasmic processes and contain NF proteins in the processes as in the cell bodies. With regard to the exocrine property, immunoreactivity of amylase decreases and finally disappears as the processes extend (Fig. 3). These data clearly document the chronological relationship of the expression of characteristics of exocrine and neuronlike cells.

Our data reveal the changes in microtubule organization in AR42J cells treated with activin A. The bundle formation of microtubules is unique in neuron and neuronal cells (38). Re-

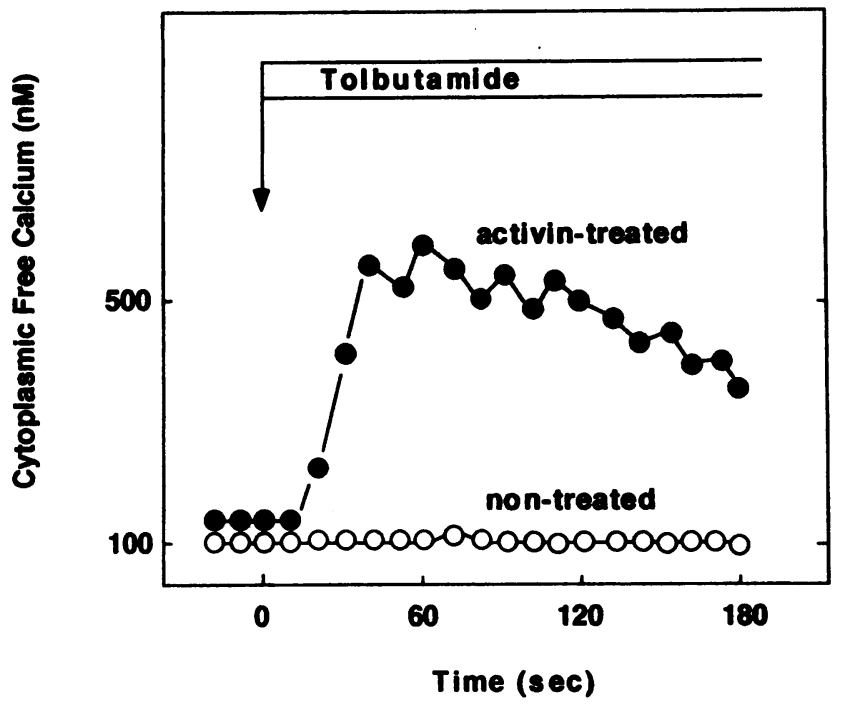

Figure 11. Effect of tolbutamide on cytoplasmic free calcium concentration in activin A-treated and untreated AR42J cells. AR42J cells were incubated for $10 \mathrm{~d}$ with or without $4 \mathrm{nM}$ activin A. Fura-2-loaded activin-treated $(\bullet)$ or untreated $(O)$ cells were stimulated with $50 \mu \mathrm{M}$ tolbutamide, and changes in $\left[\mathrm{Ca}^{2+}\right]_{c}$ were monitored. Representative responses are presented. 


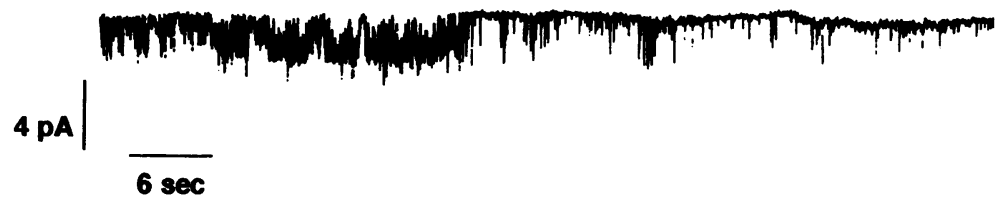

Figure 12. ATP-sensitive potassium channel current in activin A-treated AR42J cell. Transmembrane potassium current was measured in an inside-out mode of patch clamp as described in Methods. ATP ( $1 \mathrm{mM})$ was added into the bath as indicated. cent studies showed that nonneuronal cells such as $\mathrm{L}$ cells and Sf9 cells formed microtubule bundles when MAP-2 or tau was transfected $(31,39,40)$. These studies demonstrate that MAP2 and tau regulate microtubule organization. However, the observation that fibroblasts induced to express tau do not extend processes (39) suggests that an additional factor ( $\mathrm{s}$ ) is necessary for process elongation (31). Since activin A elicits extension of processes with microtubule bundling and cross-bridges of MAP-2, activin-treated AR42J cells may have these factors, which are indispensable to neurons.

During the course of our studies on the activin A-induced morphological changes in AR42J cells, we realized that the properties of activin-treated cells resembled those of pancreatic endocrine cells. We therefore analyzed the electrophysiological properties of activin-treated AR42J cells. As demonstrated in Fig. 9, elevation of $\left[\mathrm{Ca}^{2+}\right]_{c}$ in response to high potassium is markedly increased in activin-treated AR42J cells. An analysis of voltage-dependent calcium channel current, however, indicates that calcium channel current is not changed in activintreated cells. Instead, activin-treated cells exhibit marked elevation of $\left[\mathrm{Ca}^{2+}\right]_{\mathrm{c}}$ in response to caffeine. Since caffeine causes calcium release from the intracellular pool involved in CICR, the results are consistent with the idea that CICR operates in activin-treated cells. Taken together, a marked increase in $\left[\mathrm{Ca}^{2+}\right]_{\mathrm{c}}$ in response to depolarizing concentration of potassium observed in activin-treated cells may result from the expression of CICR system, which is shown to play an important role in pancreatic endocrine cells (41). An analysis of the molecular properties of VDCC in activin-treated AR42J cells has revealed intriguing information. As shown in Fig. 10, RT-PCR reveals the expression of mRNA for neuroendocrine/ $\beta$ cell-type VDCC $\alpha_{1}$ subunit in AR42J cells. This $\alpha_{1}$ subunit is cloned with the PCR method using skeletal muscle VDCC as a guide sequence, and it is shown to be expressed specifically in $\beta$ cells of rat pancreatic islets and considered to play a role in the regulation of insulin secretion (26). However, it is not expressed in all insulin-secreting cell lines; for example, it is expressed in RINm5F and $\beta$ TC- 3 cells but not in HIT-T15 cells (26). Hence, its expression in AR42J cells implies the potential islet cell-like property of activin-treated AR42J cells. Note that neuroendocrine/ $\beta$ cell-type VDCC may be a minor component of VDCCs expressed in AR42J, since the treatment with activin A does not significantly alter the amplitude of VDCC current. Tolbutamide is a member of the sulfonylureas and is widely used for the treatment of human diabetes. In $\beta$ cells, tolbutamide binds to the $\mathrm{K}_{\mathrm{ATP}}$ channel or related protein, the sulfonylurea receptor, and inhibits the activity of $\mathrm{K}_{\mathrm{ATP}}$ channels. Resulting depolarization of the plasma membrane leads to opening of VDCC. In activin A-treated AR42J cells, tolbutamide increases $\left[\mathrm{Ca}^{2+}\right]_{c}$, while tolbutamide has no effect in nontreated cells. Moreover, we demonstrate the existence of $\mathrm{K}_{\mathrm{ATP}}$ channel in activin-treated AR42J cells by single channel recording (Fig. 12 ). Hence, AR42J cells express both $K_{A T P}$ channel and neuroendocrine/ $\beta$ cell-type VDCC $\alpha_{1}$ subunit. Despite the fact that the former is not specific to pancreatic endocrine cells, the expression of two types of channels suggests that activin-treated AR42J cells resemble pancreatic endocrine cells in their electrophysiological characteristics.

Pancreatic endocrine cells, for example, insulin-secreting $\beta$ cells, have many properties characteristic of neuronal cells: They extend neurites when cultured in vitro (42); they express various neuroectodermal antigens including tyrosine hydroxylase (43), synaptophysin (44), $\gamma$-aminobutylic acid transporters, and neuron-specific enolase (45); and the plasma membrane of these cells is electrophysiologically excitable. Although pancreatic endocrine cells express neuronal markers, it is generally believed that the pancreatic duct in embryos contains undifferentiated precursor cells that migrate from the duct to originate endocrine and acinar cells (46). In the embryonic pancreas, putative precursor cells become differentiated and eventually express neuronlike properties. Also, these precursor cells can differentiate into acinar cells. Given that amphicrine AR42J cells become differentiated into acinar-like cells in response to dexamethasone (17) and into neuronlike cells in response to activin A, AR42J cells may provide an in vitro model system to study the differentiation of neuroendocrine and exocrine cells in the pancreas. Despite the fact that AR42J cells are transformed cells, they may be useful to study the differentiation of acinar-like cells in vitro. In this regard, our recent study demonstrates that immunoreactive activin $\mathrm{A}$ is expressed in the embryonic pancreatic anlage (47). It is an interesting possibility that activin A expressed in endocrine precursor cells of the embryonic pancreas may modulate differentiation of the putative precursor cells.

\section{Acknowledgments}

The authors are grateful to Dr. Jun Takeda for valuable suggestions and to Dr. Norio Kawamura (Japanese Cancer Institute) for critical reading of the manuscript.

The present study was supported by a Grant-in-Aid for Scientific Research (The Ministry of Education, Science and Culture of Japan). 


\section{References}

1. Vale, W., J. Rivier, J. Vaughan, R. McClintock, A. Corrigan, W. Woo, D. Karr, and J. Spiess. 1986. Purification and characterization of FSH releasing protein from porcine ovarian follicular fluid. Nature (Lond.). 321:776-779.

2. Ying, S. Y. 1988. Inhibins, activins and follistatins: gonadal proteins modulating the secretion of follicle-stimulating hormone. Endocr. Rev. 9:267-293.

3. Katayama, T., K. Shiota, and M. Takahashi. 1990. Activin A increases the number of follicle-stimulating hormone cells in anterior pituitary cultures. $\mathrm{Mol}$. Cell. Endocrinol. 69:179-185.

4. Sugino, H., T. Nakamura, Y. Hasegawa, K. Miyamoto, Y. Abe, M. Igarashi, Y. Eto, H. Shibai, and K. Titani. 1988. Erythroid differentiation factor can modulate follicular granulosa cell functions. Biochem. Biophys. Res. Commun. 153:281-288.

5. Eto, Y., T. Tsuji, M. Kakegawa, S. Takano, T. Yokogawa, and H. Shibai. 1987. Purification and characterization of erythroid differentiation factor isolated from human leukemia cell line, THP-1. Biochem. Biophys. Res. Commun. 142:1095-1100.

6. Yu, J., L. Shao, V. Leman, A. L. Yu, J. Vanghan, J. Rivier, and W. Vale. 1987. Importance of FSH-releasing protein and inhibin in erythroid differentiation. Nature (Lond.). 330:765-767.

7. Nishimura, M., K. Kaku, Y. Azuno, K. Okafuji, Y. Eto, M. Shiozaki, H. Sasaki, T. Inoue, and T. Kaneko. 1991. Effect of erythroid differentiation factor on megakaryocytic differentiation of L8057, a murine megakaryoblastic leukemia cell line. Biochem. Biophys. Res. Commun. 181:1042-1047.

8. Yasuda, H., T. Mine, H. Shibata, Y. Eto, Y. Hasegawa, T. Takeuchi, S. Asano, and I. Kojima. 1993. Activin A: an autocrine inhibitor of initiation of DNA synthesis in rat hepatocytes. J. Clin. Invest. 92:1491-1496.

9. Schubert, D., H. Kimura, M. La Corbiere, J. Vaughan, D. Karr, and W. H. Fischer. 1990. Activin is a nerve cell survival molecule. Nature (Lond.). 344:868870.

10. Hashimoto, M., S. Kondo, Y. Sakurai, Y. Eto, H. Shibai, and M. Muramatsu. 1990. Activin/EDF as an inhibitor of neural differentiation. Biochem. Biophys. Res. Commun. 173:193-200.

11. Smith, J. C., B. M. J. Price, K. Van Nimmen, and D. Huylebroeck. 1990. Identification of a potent Xenopus mesoderm-inducing factor as a homologue of activin A. Nature (Lond.). 345:729-734.

12. Sokol, S., and D. A. Melton. 1991. Pre-existent pattern in Xenopus animal pole cells revealed by induction with activin. Nature (Lond.). 351:409-411.

13. Hemmati-Brivanlou, A., and D. A. Melton. 1994. Inhibition of activin receptor signaling promotes neuralization in Xenopus. Cell. 77:272-281.

14. Yasuda, H., S. Tanaka, H. Ohnishi, H. Mashima, N. Ohgushi, T. Mine, and I. Kojima. 1994. Activin A: negative regulator of amylase secretion and cell proliferation in pancreatic acinar AR42J cells. Am. J. Physiol. 267:G220-G226.

15. Kusano, K., and H. Gainer. 1991. Whole cell current analysis of pancreatic acinar AR42J cells. Am. J. Physiol. 260:C934-C948.

16. Rosewicz, S., D. Vogt, N. Harth, C. Grund, W. W. Franke, S. Ruppert, E. Schweitzer, E. O. Riecken, and B. Wiedenmann. 1992. An amphicrine pancreatic cell line: AR42J cells combine exocrine and neuroendocrine properties. Eur. J. Cell Biol. 59:80-91.

17. Logsdon, C. D., J. Moessner, J. A. Williams, and I. D. Goldfine. 1985. Glucocorticoids increase amylase mRNA levels, secretory organelles, and secretion in pancreatic acinar AR42J cells. J. Cell Biol. 100:1200-1208.

18. Alexander, J. J., E. M. Bey, E. W. Geddes, and G. Lecatsas. 1976. Establishment of a continuously growing cell line from primary carcinoma of the liver. S. Afr. Med. J. 50:2124-2128.

19. Liem, R. K. H., and S. B. Hutchinson. 1982. Purification of individual components of the neurofilament triplet. Biochemistry. 21:3221-3226.

20. Shiomura, Y., and N. Hirokawa. 1987. Colocalization of microtubuleassociated protein $1 \mathrm{~A}$ and microtubule-associated protein 2 on neuronal microtubules in situ revealed with double-label immunoelectron microscopy. J. Cell Biol. 104:1575-1578.

21. Laemmli, U. K. 1970. Cleavage of structural proteins during the assembly of the head of bacteriophage T4. Nature (Lond.). 227:680-685.

22. Drubin, D. G., S. C. Feinstein, E. M. Shooter, and M. W. Kirschner. 1985. Nerve growth factor-induced neurite outgrowth in PC12 cells involves the coordinate induction of microtubule assembly and assembly-promoting factors. J. Cell Biol. 101:1799-1807.

23. Lowry, O. H., N. J. Rosebrough, A. L. Farr, and R. J. Randall. 1951. Protein measurement with the Folin phenol reagent. J. Biol. Chem. 193:265-275.
24. Murata, F., S. Tsuyama, K. Thida, N. Koshio, M. Kawano, and Z. Z. Li 1992. Sulfated glycoconjugates demonstrated in combination with high iron diamine thiocarbohydrazide-silver proteinate and silver acetate physical development. J. Electron Microsc. 41:14-20.

25. Iwashima, Y., A. Abiko, S. Seino, J. Takeda, M. Eto, K. S. Polonsky, and I. Makino. 1994. Reduced level of messenger ribonucleic acid for calcium channel, glucose transporter-2 and glucokinase are associated with alterations in insulin secretion in fasted rats. Endocrinology. 135:1010-1017.

26. Seino, S., L. Chen, M. Seino, O. Blondel, J. Takeda, J. H. Johnson, and G. I. Bell. 1992. Cloning of the $\alpha_{1}$ subunit of a voltage-dependent calcium channel expressed in pancreatic $\beta$ cells. Proc. Natl. Acad. Sci. USA. 89:584-588.

27. Kojima, I., H. Mogami, and E. Ogata. 1992. Oscillation of cytoplasmic free calcium induced by insulin-like growth factor-I in Balb/c 3T3 cells. Am. J. Physiol. 262:E307-E311.

28. Hamil, O. P., M. E. Neher, B. Sakmann, and F. J. Sigworth. 1981. Improved patch-clamp techniques for high-resolution current recording from cells and cell-free membrane patches. Pflueg. Arch. Eur. J. Physiol. 391:85-100.

29. Rae, J., K. Cooper, P. Gates, and M. Watsky. 1991. Low access resistance perforatreds patch recording using amphotericin B. J. Neurosci. Methods. 37:1525 .

30. Sharp, G. A., K. Weber, and M. Osborn. 1982. Centriole number and process formation in established neuroblastoma cells and primary dorsal root ganglion neurons. Eur. J. Cell Biol. 29:97-103.

31. Baas, P. W., T. P. Pienkowski, and K. S. Kosik. 1991. Processes induced by tau expression in Sf 9 cells have an axon-like microtubule organization. $J$. Cell Biol. 115:1333-1344.

32. Goedert, M., R. A. Crowther, and C. C. Garner. 1991. Molecular characterzation of microtubules-associated proteins tau and MAP2. Trends Neurosci. 14:193-199.

33. Bernhard, R., and A. Matus. 1984. Light and electron microscopic studies of the distribution of microtubules-associated protein 2 in rat brain. J. Comp. Neurol. 226:203-221.

34. Hirokawa, N., S. Hisanaga, and Y. Shimomura. 1988. MAP2 is a component of crossbridges between microtubules and neurofilaments in the neuronal cytoskeleton. J. Neurosci. 8:2769-2779.

35. Black, M. M., and P. W. Baas. 1989. The basis of polarity in neurons. Trends Neurosci. 12:211-214.

36. Hoffman, P. N., and R. J. Lasek. 1975. The slow component of axonal transport. J. Cell Biol. 66:351-366.

37. Schlaepfer, W. W., and R. G. Lynch. 1977. Immunofluorescence studies of neurofilaments in rat and human peripheral and central nervous system. J. Cell Biol. 74:241-250.

38. Brugg, B., and A. Matus. 1988. PC12 cells express juvenile microtubuleassociated proteins during nerve growth factor-induced neurite outgrowth. $J$. Cell Biol. 107:643-650.

39. Kanai, Y., R. Takemura, T. Oshima, H. Mori, Y. Ihara, M. Yanagisawa T. Masaki, and N. Hirokawa. 1989. Expression of multiple tau isoforms and microtubule bundle formation in fibroblasts transfected with a single tau cDNA. J. Cell Biol. 109:1173-1184.

40. Chen, J., Y. Kanai, N. J. Cowan, and N. Hirokawa. 1992. Projection domains of MAP2 and tau determine spacings between microtubules in dendrites and axons. Nature (Lond.). 360:674-677.

41. Takasawa, S., K. Nata, H. Yonekura, and H. Okamoto. 1993. Cyclic ADPribose in insulin secretion from pancreatic $\beta$-cells. Science (Wash. DC). 259:370373.

42. Teitelman, G. 1990. Insulin cells of pancreas extend neurites but do not arise from the neuroectoderm. Dev. Biol. 142:368-379.

43. Teitelman, G., and J. K. Lee. 1987. Cell lineage analysis of pancreatic islet cell development: glucagon and insulin cell arise from catecholaminergic precursors present in pancreatic duct. Dev. Biol. 121:454-466.

44. Weidenmann, B., W. W. Franke, C. Kuhn, R. Moll, and V. E. Gould. 1986. Synaptophysin: a marker protein for neuroendocrine cells and neoplasm. Proc. Natl. Acad. Sci. USA. 83:3500-3504.

45. Polak, J. M., S. R. Bloom, and P. J. Marango. 1984. Neuron-specific enolase, a marker for neuroendocrine cells. In Evolution and Tumor Pathology of the Neuroendocrine System. S. Falkmer, R. Hakanson, and F. Sundler, editors. Elsevier Science Publishing Co., Amsterdam. 433-460.

46. Pictet, R., and W. J. Rutter. 1972. Development of the embryonic endocrine pancreas. In Handbook of Physiology. Vol. 1. D. F. Steiner and M. Frenkel, editors. American Physiological Society, Washington, DC. 25-66.

47. Furukawa, M., and I. Kojima. 1995. Expression of immunoreactive activin A in fetal rat pancreas. Endocr. J. 42:63-68. 